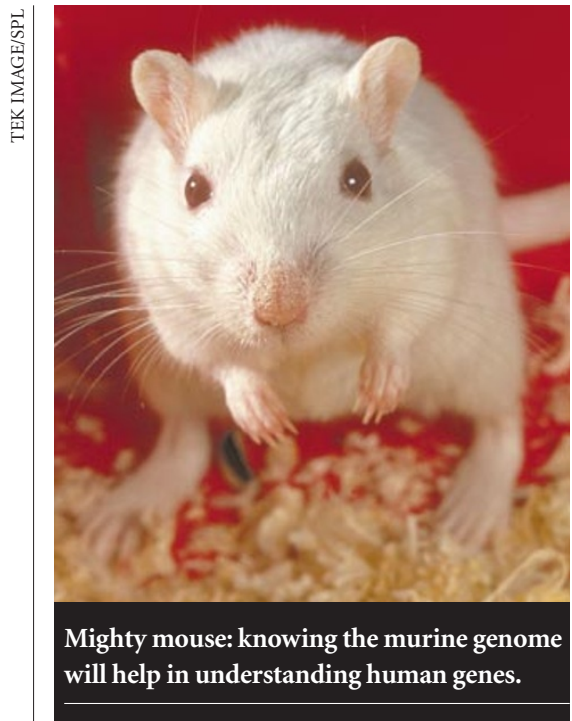

- Celera's effort will allow subscribers to detect subtle differences between strains; the public project will give a more complete view of one strain.

But Celera president Craig Venter sees duplication, not difference. The consortium's effort is a "waste of public money", he says. "It would make more sense for scientists to pay for Celera licences than to pay for the genome to be sequenced again."

Roger Schultz, assistant professor of human growth and development at the University of Texas Southwestern Medical Center, sees merit in the public approach, which aims to sequence both mouse and human genomes several times more than Celera intends.

"Personally, I'm more interested in the high-quality human product, although a good mouse project can help you find highly conserved regions, and therefore genes," he says. The Texas centre is one Celera's several academic subscribers.

Celera subscribers will get the first view of the mouse, as the company expects to finish sequencing next month. If the public project finishes its first phase in March, as planned, the data could be largely assembled by the end of next year. Plans announced by the Human Genome Project last autumn called for a draft of the mouse by the end of 2003, to be fully completed by the end of 2005 .

The Whitehead Institute at the Massachusetts Institute of Technology, Washington University in St Louis, and the British Sanger Centre near Cambridge will do the bulk of the public project's shotgun sequencing. Washington University is halfway through building a map of the mouse that will help in assembling a rough draft from the mouse shotgun data. http://www.nhgri.nih.gov/NEWS/MouseGenes/ mouse_release.html

\title{
Anger as Spain boosts R\&D figures with defence money
}

\section{Xavier Bosch, Barcelona}

Spanish scientists are expressing anger that the government is exaggerating its generosity towards research by including a number of military projects in the national research and development (R\&D) budget.

Late last month, the Spanish government announced an $11.3 \%$ increase in next year's state spending on $\mathrm{R} \& \mathrm{D}$, following agreement by the cabinet to boost $\mathrm{R} \& \mathrm{D}$ spending by Ptas 572 billion (US $\$ 3$ billion).

According to a report accompanying the budget figures, basic and applied research managed by the Higher Council of Scientific Research (CSIC) and the Ministry of Health will receive a $7.6 \%$ increase to Ptas 112 billion. But a significantly larger increase of $12.6 \%$ will go to the general categories of 'technological R\&D' and 'information society R\&D'.

The government report says this spending is intended to boost "competitive technological research as well as to finance the development of the information society". But Ramón Marimon, secretary of state for scientific policy at the Ministry of Science and Technology (MST), admits that the budget for 'technological R\&D' - the largest item in the whole R\&D budget at about Ptas 300 billions - is devoted to technological projects for military use.

According to information on the website of the former Ministry of Industry and Energy, which has been replaced by the MST, the minister has allocated Ptas 500 billion since 1997 to the Ministry of Defence for the construction of tanks, frigates and fighter planes. These funds have been officially listed as ' $R \& D$ ' funds, and their military nature has not been explicitly stated.

This military spending may explain the impressive growth of the nation's R\&D budget from Ptas 207 billion in 1995 to 507 billion in 2000, which, according to the budget report, supposes "a cumulative annual mean rate [of R\&D investment] of 19.6\%".

"Not only is the government trying to disguise the true situation, but a significant

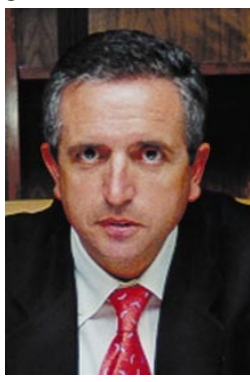
amount of the $R \& D$ budget is spent on military research, while the money set aside for [civilian] research remains scarce," says Óscar Fornas, a senior biomedical researcher at the University of Barcelona.

The MST has Marimon: admits to military spending. the proportion of gross

\section{LATEST SPANISH MILITARY CAMOUFLAGE UNVEILED!}

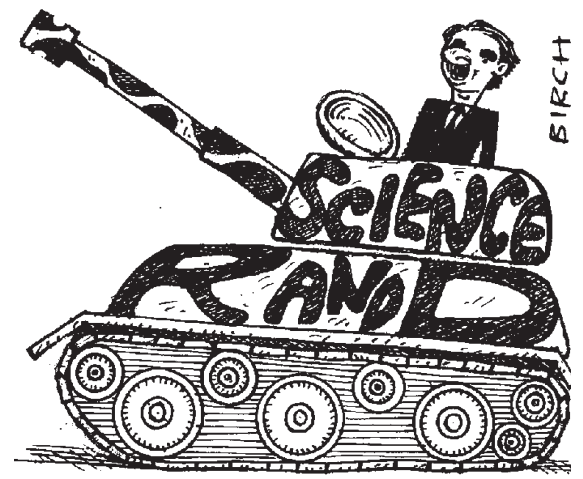

national product spent on research from $0.9 \%$ to $2 \%$ by 2003 , in line with other advanced countries.

But if this figure is reached by devoting a disproportionate amount of funds to military research, then "something is very wrong", says Jordi Camí, professor of pharmacology at the University Pompeu Fabra in Barcelona.

Mariano Esteban Rodriguez, director of the National Centre of Biotechnology in Madrid, says scientists "must know how much money there really is for research", and adds that "transparency is essential to know how much money we can spend".

Luis Rull, professor of physics at the University of Seville, says the situation was the same last year, when it was criticized by the Spanish Association for the Advancement of Science and Technology.

Spaniard Juan Manfredi, professor of mathematics at the University of Pittsburgh, says the way the Spanish budget is presented is significantly different from the situation in the United States, where a clear distinction is made between civilian and military spendings on research.

He adds that a line in the Spanish budget described as military R\&D ('research and studies of armed forces') should not be included in the research budget, as most of the money "represents the adaptation and fitting of existing technologies".

While admitting the substantial spending on military projects, Marimon points out that at least 2,000 new research posts will be created in the public sector.

He has also announced that companies involved in $\mathrm{R} \& \mathrm{D}$ will no longer pay value added tax (VAT) on their activities. But he admits that it would be "reasonable" to increase the amount of transparency in the Spanish budget in the future, and promises to try to achieve this. 